\title{
Berpikir Reflektif Matematis Siswa dalam Menyelesaikan Soal Garis Singgung Lingkaran Berdasarkan Kemampuan Matematika
}

\author{
${ }^{1}$ Wa Ode Adenia, ${ }^{2}$ Nurma Angkotasan, ${ }^{3}$ Joko Suratno \\ ${ }^{1,23}$ Program Studi Pendidikan Matematika Universitas Khairun
}

\begin{abstract}
ABSTRAK
Penelitian ini bertujuan untuk mendeskripsikan kemampuan berpikir reflektif matematis siswa dalam menyelesaikan soal persamaan garis singgung lingkaran berdasarkan kemampuan matematika. Jenis penelitian dalam penelitian ini adalah kualitatif deskriptif. Metode yang digunakan adalah instrumen tes dan wawancara. Teknik analisis data dalam penelitian ini adalah mentranskip data verbal, kategorisasi data, reduksi data, triangulasi data, menelaah data dan verifikasi data. Subjek penelitian ini adalah subjek S-29 dan S-15 yang berkemampuan tinggi, S-36 dan S-22 yang berkemampuan sedang dan S-16 dan S-18 yang berkemampuan rendah. Hasil penelitian berpikir reflektif matematis siswa dalam menyelesaikan soal garis singgung lingkaran sebagai berikut: 1) subjek S-29 dan S-15 mampu berpikir reflektif dimana telah memahami masalah yang diberikan dengan benar, mampu mengkomunikasikan ide dalam bentuk simbol/gambar, mampu menghubungkan pengetahuan baru dengan pemahaman terdahulu yang dimilikinya, mampu menghubungkan informasi-informasi dalam menyelesaikan soal yang diberikan sehingga dapat menarik kesimpulan dari jawaban akhir dan menyadari kesalahan kemudian memperbaiki dan atau tidak melakukan kesalahan dan membuktikan kebenaran jawaban yang diperoleh, 2) subjek S-36 dan S-22 mampu berpikir reflektif dimana telah memahami masalah yang diberikan dengan benar, mampu mengkomunikasikan ide dalam bentuk simbol/gambar, mampu menghubungkan pengetahuan baru dengan pemahaman terdahulu yang dimilikinya, berusahan menghubungkan informasi-informasi yang dimiliki meskipun mengalama kesulitan dalam menyelesaikannya, dan menyadari kesalahan dalam menggunakan keterampilan menghitung lalu memperbaikinya tetapi tidak memperoleh jawaban akhir dari soal, dan 3) subjek S-16 dan S-18 dalam berpikir reflektif hanya mampu memahami masalah dengan benar dan mampu mengkomunikasikan ide dalam bentuk simbol/gambar, sedangkan dalam menghubungkan pengetahuan baru dengan pemahaman terdahulu yang dimiliki, dan informasi-informasi dalam menyelesaikan soal yang diberikan nampak bahwa subjek berusaha untuk menyelesaikan soal dan subjek menyadari kesalahan dalam menggunakan keterampilan menghitung lalu memperbaikinya tetapi tidak memperoleh jawaban akhir dari soal.
\end{abstract}

\section{Kata kunci: kemampuan berpikir reflektif, garis singgung lingkaran dan kemampuan matematika.}




\section{PENDAHULUAN}

Menurut UU No. 23 tahun 2003 tentang Sistem Pendidikan Nasional Bab IV Pasal 3, sebagaimana dikutip oleh Achmad Munif dkk (2012: 20), Pendidikan Nasional berfungsi untuk mengembangkan kemampuan dan membentuk watak serta peradaban bangsa yang bermartabat dan dalam rangka mencerdaskan kehidupan bangsa, bertujuan untuk berkembangnya peserta didik agar menjadi manusia yang beriman, bertaqwa kepada Tuhan Yang Maha Esa, berakhlak mulia, sehat, berilmu, cakap, kreatif, mandiri, dan menjadi warga negara yang demokrasi serta bertanggungjawab.

Menurut Mudyaharjo (2010: 476), pendidikan adalah pengalaman belajar yang berlangsung dengan baik dalam lingkungan budaya masyarakat yang merupakan hasil rekayasa manusia, maupun dalam lingkungan alam yang terjadi dengan sendirinya tanpa rekayasa manusia. Pendidikan merupakan usaha yang secara sadar dilakukan oleh manusia dalam rangka menuju ke arah hidup yang lebih baik. Tujuan pendidikan dapat tercapai dengan optimal, maka guru sebagai pendidik dituntut untuk selalu mengembangkan proses pembelajaran agar sesuai dengan kondisi dan perkembangan zaman. Salah satu mata pelajaran wajib yang harus dipelajari siswa adalah matematika.

Menurut Johnson dan Rising (Mentari, Nindiasari dan Pamungkas, 2018: 75), matematika adalah pola berpikir, pola mengorganisasikan, pembuktian yang logis, matematika itu adalah bahasa yang menggunakan istilah didefinisikan dengan cermat jelas, dan akurat, representasinya dengan simbol dan padat. Matematika sebagai sebuah cabang ilmu pengetahuan tidak hanya sekedar berisikan rumus-rumus yang digunakan untuk menyelesaikan sebuah soal dan juga tidak hanya ilmu yang berisikan simbol atau notasi yang terkadang sulit dimengerti oleh siswa. Menurut Ningsih (Mentari, Nindiasari dan Pamungkas, 2018: 72), belajar matematika melibatkan proses berpikir dalam diri setiap manusia, untuk mencapai berbagai macam kompetensi, keterampilan dan sikap. Berpikir merupakan kegiatan meletakan hubungan antar bagian pengetahuan. Berpikir selalu dilakukan oleh setiap orang atau 
individu, dengan demikian berpikir bersifat internal, muncul dalam diri individu dan berlangsung terus-menerus.

Kemampuan berpikir matematis terdiri dari kemampuan berpikir logis, kemampuan berpikir kritis, kemampuan berpikir kreatif dan kemampuan berpikir reflektif. Kemampuan-kemampuan tersebut biasa disebut dengan kemampuan berpikir tingkat tinggi (high order thinking skill), (Kusumaningrum dan Saefudin, 2012: 573). Keempat kemampuan berpikir tingkat tinggi tersebut, terdapat kemampuan berpikir matematika yang belum dikembangkan oleh sebagian guru di Indonesia yaitu kemampuan berpikir reflektif matematis siswa. Hal ini mengakibatkan kemampuan berpikir reflektif matematis siswa masih tergolong rendah. Hal ini sejalan dengan penelitian yang dilakukan Nindiasari (Mentari, Nindiasari dan Pamungkas, 2018: 72), dalam studi pendahuluannya terhadap sejumlah siswa SMA di Tangerang memperoleh beberapa temuan diantaranya: Dalam mengajarnya, guru lebih banyak memberikan rumus dan konsep matematika yang sudah jadi dan tidak mengajak siswa berpikir untuk menemukan rumus dan konsep matematika yang dipelajarinya; Hampir lebih dari 60\% siswa belum mampu menyelesaikan tugas-tugas berpikir reflektif matematis, misalnya tugas menginterpretasi, mengaitkan, dan mengevaluasi.

SMA Negeri 1 Kota Ternate merupakan salah satu sekolah yang memiliki kemampuan matematis yang rendah. Hal ini diperoleh dari hasil wawancara dengan salah satu guru matematika peminatan yaitu Ibu Musawati, S.Pd selaku guru pamong dan beberapa siswa pada saat peneliti melaksanakan Prakter Pengalaman Lapangan (PPL) II di sekolah tersebut. Hasil wawancara diperoleh bahwa banyak siswa yang mengalami kesulitan belajar matematika dalam memahami konsep garis singgung lingkaran. Beberapa kesulitan siswa misalnya pada saat diberikan masalah konstektual, siswa cenderung tidak tahu apa yang harus dilakukan dan darimana siswa mulai menjawabnya, serta siswa lemah dalam proses analisis. Siswa kesulitan menghubungkan pengetahuan lama yang dimilikinya yang berguna untuk mendapatkan pengetahuan baru yang sedang dipelajari. Apabila siswa ditanya 
mengenai pendapatnya, siswa merasa takut, gugup dan tegang dalam mengungkapkan pendapatnya terkait penyelesaaian masalah yang ada. Selain itu juga, di sekolah ini belum pernah diadakan penelitian yang menganalisis kemampuan berpikir reflektif matematis siswa dalam menyelesaikan soal garis singgung lingkaran.

Peneliti melakukan observasi pada hari Jumat tanggal 16 November 2018 di kelas XI MIA-6 SMA Negeri 1 Kota Ternate dengan jumlah siswa sebanyak 36 orang. Peneliti kemudian memberikan tes tertulis tentang materi garis singgung lingkaran yang pernah dipelajari di kelas VIII sebanyak 3 butir soal yang memuat aspek kemampuan koneksi matematis, kemampuan penalaran matematis dan kemampuan berpikir reflektif. Berikut ini diagram hasil tes studi pendahuluan yang peneliti lakukan dapat digambarkan sebagai berikut:

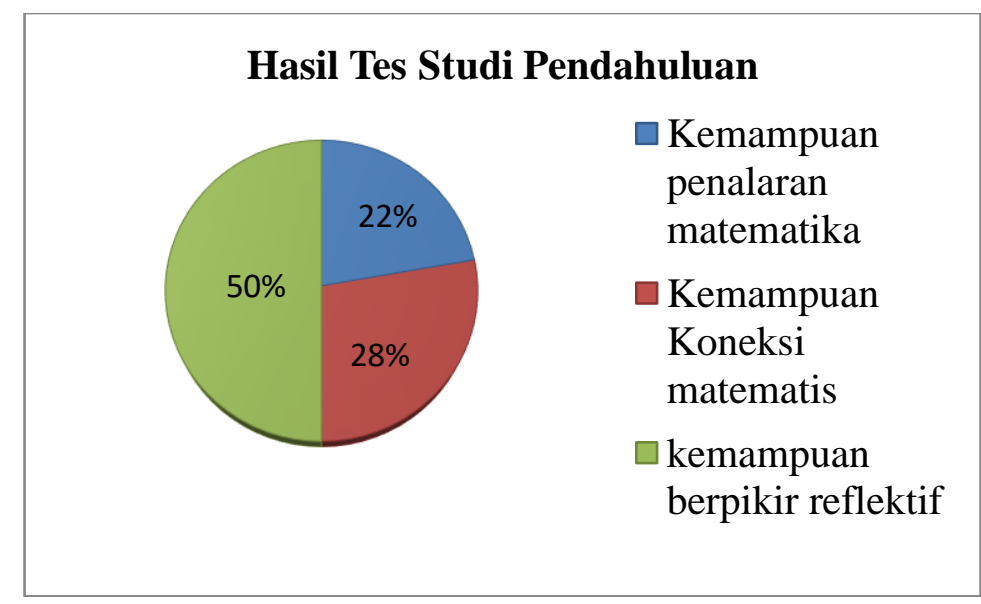

Gambar 1

Diagram Hasil Tes Pendahuluan

Berdasarkan diagram pada gambar 1, diperoleh presentasi hasil tes siswa yaitu sebagai berikut:

1. $22 \%$ dari 36 siswa atau sebanyak 8 orang yang belum mampu menyelesaikan soal dengan aspek kemampuan penalaran matematis

2. $28 \%$ dari 36 siswa atau sebanyak 10 orang yang belum mampu menyelesaikan soal dengan aspek kemampuan koneksi matematis 
3. $50 \%$ dari 36 siswa atau sebanyak 18 orang yang belum mampu menyelesaikan soal dengan aspek kemampuan berpikir reflektif.

Diagram tersebut menunjukan bahwa tingkat presentase kesulitan paling besar yaitu 50\%, yang menunjukan adanya kesulitan peserta didik dalam menyelesaikan kemampuan berpikir reflektif matematis siswa kelas XI MIA 6. Berikut hasil kerja salah satu siswa dalam menyelesaikan soal garis singgung lingkaran:

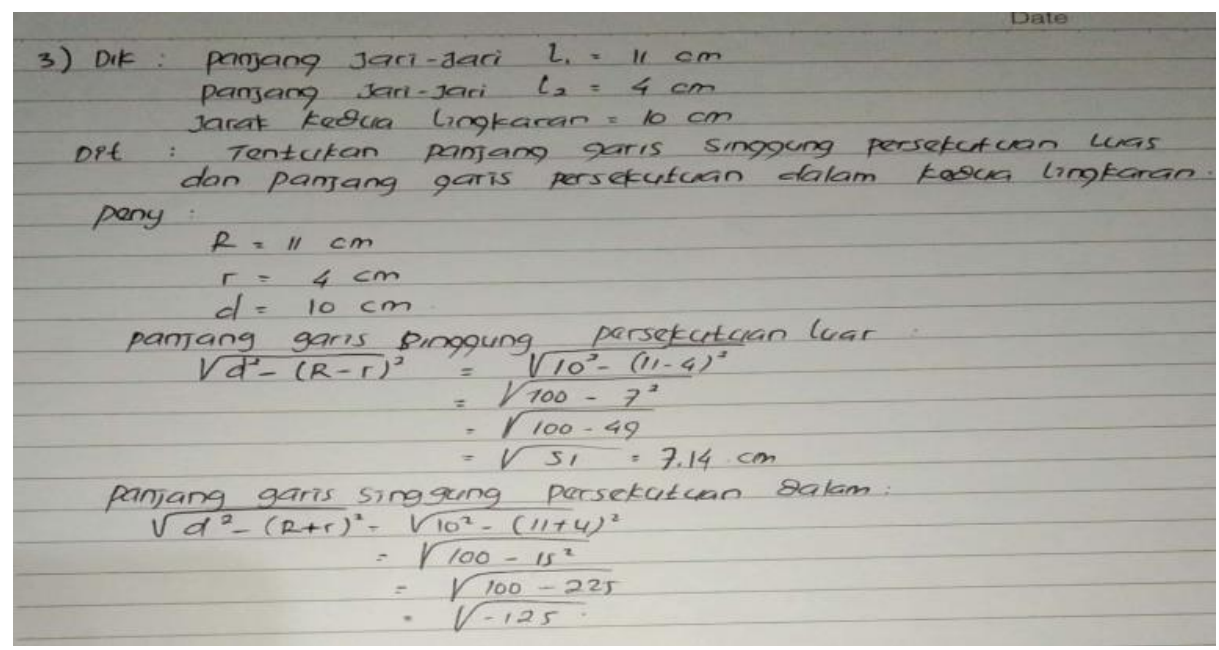

\section{Gambar 2}

\section{Hasil Pekerjaan Siswa}

Hasil pekerjaan siswa di atas, menunjukan siswa hanya mampu memahami masalah dengan menuliskan apa yang diketahui dan apa yang ditanyakan, tetapi siswa masih mengalami kesulitan dalam mengkomunikasikan ide dalam bentuk simbol atau gambar sehingga belum mampu menyelesaiakan hingga memperoleh jawaban akhir. Salah satu faktor penyebabnya adalah kecenderungan siswa dalam mempelajari matematika fokus pada masalah hafalan rumus dalam menyelesaikan masalah. Oleh karena itu, peneliti menyimpulkan siswa belum mampu menyelesaikan masalah matematika pada aspek kemampuan berpikir reflektif. 


\section{METODE PENELITIAN}

Penelitian ini bertujuan untuk mendeskripsikan kemampuan berpikir reflektif matematis siswa dalam menyelesaikan soal persamaan garis singgung lingkaran berdasarkan kemampuan matematika. Jenis penelitian dalam penelitian ini adalah kualitatif deskriptif. Menurut Syoadih (Yuwono, 2010: 19), penelitian deskriptif kualitatif ditujukan untuk mendeskripsikan dan menggambarkan fenomena-fenomena yang ada, baik bersifat alamiah maupun rekayasa manusia, yang lebih memperhatikan mengenai karakteristik, kualitas, ketertarikan antar kegiatan. Bodgan dan Taylor (Basrowi dan Suwandi, 2008: 21) mendefinisikan metodologi kualitatif sebagai prosedur penelitian yang menghasilkan data deskriptif berupa kata-kata tertulis atau lisan dari orang-orang dan perilaku yang dapat di amati. Subjek penelitian ini adalah siswa kelas XII MIA-6 SMA Negeri 1 Kota Ternate. Dalam pemilihan subjek peneliti memberikan soal tes kemampuan berpikir reflektif matematis (TKBRM) untuk dikerjakan oleh siswa dan berdasarkan hasil tes dikategorikan menjadi kategori tinggi, sedang dan rendah. Kemudian dari masing-masing kategori diambil 2 orang untuk dijadikan subjek penelitian yang diwawancarai untuk memperoleh informasi yang lebih mendalam tentang kemampuan berpikir reflektif matematis siswa dalam menyelesaikan soal persamaan garis singgung lingkaran. Teknik analisis data dalam penelitian ini adalah mentranskip data verbal, kategorisasi data, reduksi data, triangulasi data, menelaah data dan verifikasi data.

\section{HASIL PENELITIAN DAN PEMBAHASAN}

Berdasarkan hasil analisis dari setiap kategori kemampuan matematika tinggi, kemampuan matematika sedang dan kemampuan matematila rendah. Hasil tersebut yang memenuhi semua indikator kemampuan berpikir refletif matematis adalah subjek dengan kemampuan matematika tinggi. Oleh karena itu, artikel ini yang diuraikan hanya subjek dengan kemampuan matematika tinggi sebagai berikut. 


\section{Pembahasan Hasil Penelitian Subjek Kemampuan Matematika Tinggi S-29 dan S-15}

Berdasarkan dari data penelitian, maka peneliti dapat menganalisis kemampuan berpikir reflektif siswa melalui tes tulis serta membandingkannya dengan hasil wawancara untuk memperkuat keabsahannya.

\section{a. Memahami Masalah}

Data ini meninjau kemampuan subjek dalam memahami masalah. Berikut hasil pekerjaan analisis dari subjek S-29.

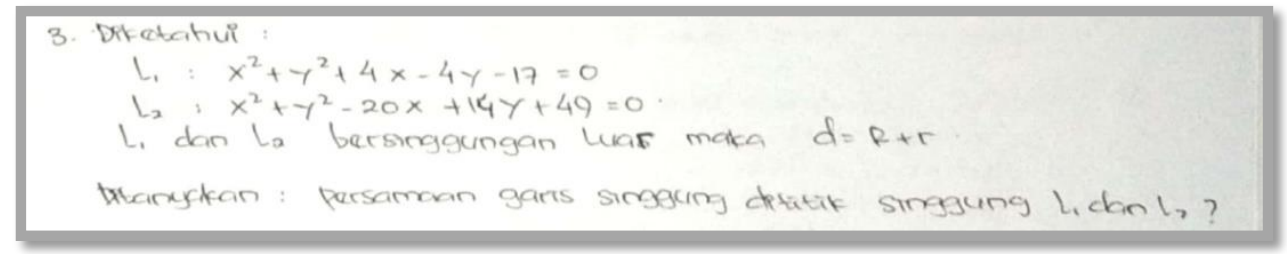

\section{Gambar 3 \\ Hasil Pekerjaan S-29}

Berdasarkan gambar 3, subjek S-29 mampu menuliskan apa yang diketahui dan apa yang ditanyakan dengan benar. Analisis ini didukung oleh petikan wawancara berikut:

P : Setelah membaca soal, apa yang diketahui dari soal itu?

S-29 : Yang diketahui yaitu lingkaran $\mathrm{L}_{1}$ dengan persamaan $\mathrm{x}^{2}+\mathrm{y}^{2}+4 \mathrm{x}-4 \mathrm{y}-17=0$ dan lingkaran $\mathrm{L}_{2}$ dengan persamaan $x^{2}+y^{2}-20 x+14 y+49=0$ saling bersinggungan di luar, maka dapat disimpulakan bahwa $d=R+r$ dimana $R$ adalah jari-jari lingkara besar $\left(L_{1}\right)$ dan $r$ adalah jari-jari lingkaran kecil $\left(\mathrm{L}_{2}\right)$

$\mathrm{P} \quad$ : Selanjutnya, apa yang ditanyakan dalam soal itu?

S-29 : tentukanlah persamaan garis singgung di titik singgung lingkaran $\mathrm{L}_{1}$ dan $\mathrm{L}_{2}$

Berdasarkan gambar 3 dan petikan wawancara di atas, terlihat bahwa subjek telah memenuhi syarat kemampuan berpikir reflektif matematis pada indikator pertama yaitu memahami masalah. 


\section{b. Mengkomunikasikan Ide dalam Bentuk Simbol atau Gambar}

Data ini meninjau kemampuan subjek dalam mengkomunikasikan ide dalam bentuk simbol atau gambar. Berikut ini hasil pekerjaan subjek S-29.
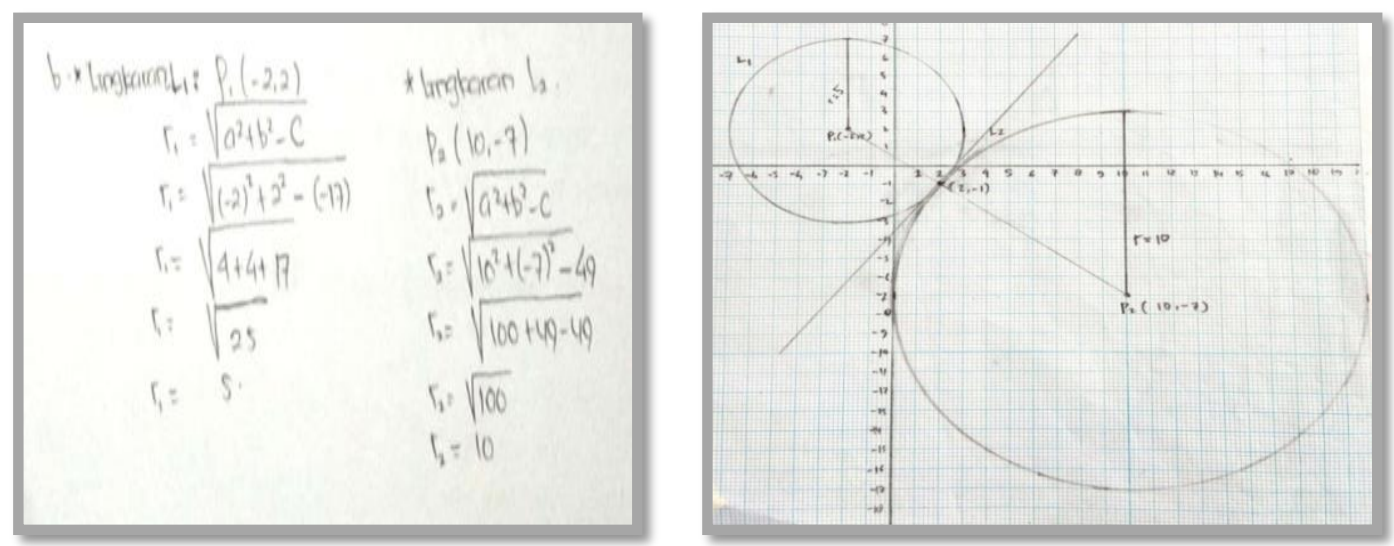

\section{Gambar 4}

\section{Hasil Pekerjaan S-29}

Berdasarkan gambar 4, menunjukan bahwa subjek telah mengkomunikasikan ide dalam bentuk gambar. Hasil analisis ini didukung oleh petikan wawancara berikut ini.

$\mathrm{P} \quad$ : Bagaimana cara Anda menggambar dua lingkaran tersebut?

S-15 : pertama, saya menentukan pusat lingkaran $L_{1}$ yaitu $(-2,2)$ dan berjari-jari 5, dan menentukan pusat lingkaran $L_{2}$ yaitu $(10,-7)$ dan berjari-jari 10, kemudian menggambar kedua lingkaran dengan menggunakan jangka..

$\mathrm{P} \quad$ : Setelah menggambar kedua lingkaran tersebut, informasi apa yang Anda peroleh?

S-15 : setelah menggambar kedua lingkaran, terlihat bahwa kedua lingkaran tersebut saling bersinggungan luar dengan titik singgungnya di $(2,-1)$. Dari titik singgung tersebut, saya menarik garis lurus melalui titik singgung kedua lingkaran tersebut sehingga terbentuklah garis singgung lingakaran yang tegak lurus dengan jari-jari kedua lingkaran tetapi persamaan garis singgung belum diketahui

Berdasarkan uraian di atas terlihat bahwa: 1) subjek mampu menjelaskan bagaimana cara menggambar lingkaran dengan benar, 2) subjek menjelaskan cara menggambar grafik persamaan garis lurus dengan benar, dan 3) subjek bisa menarik garis lurus yang melalui titk singgung lingkaran. Dengan demikian, memenuhi 
syarat kemampuan berpikir reflektif pada indikator kedua yaitu mengkomunikasikan ide dalam bentuk simbol atau gambar.

\section{c. Menghubungkan Pengetahuan Baru dengan Pemahaman Terdahulu}

Data ini meninjau kemampuan subjek dalam menghubungkan pengetahuan baru dengan pemahaman terdahulu yang dimiliki. Berikut ini hasil pekerjaan subjek S-29, yaitu:

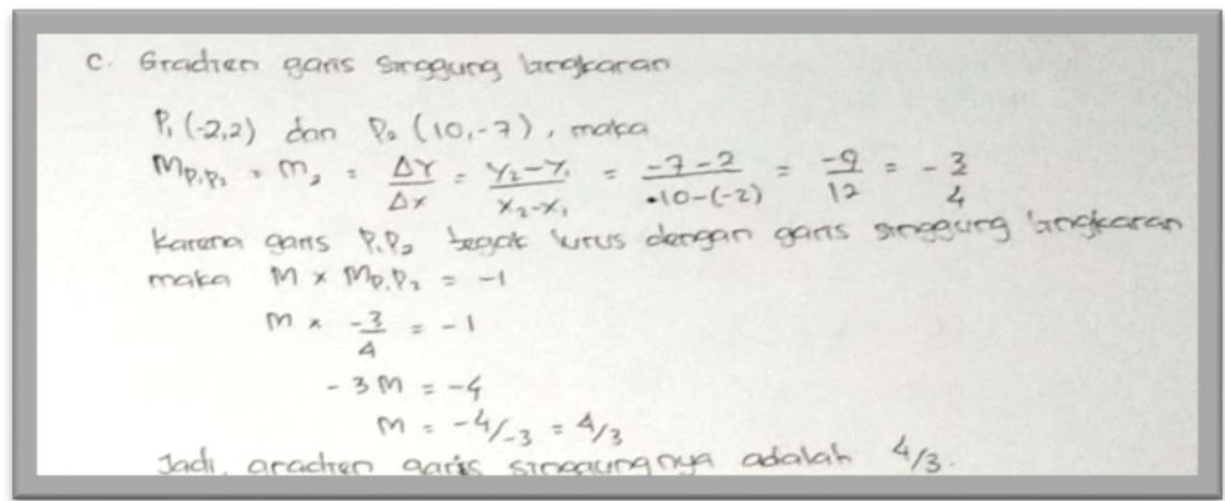

Gambar 5

\section{Hasil Pekerjaan S-29}

Berdasarkan gambar 5, menunjukan bahwa subjek telah menghubungkan pengetahuan baru dengan pemahaman terdahulu yang dimiliki. Hasil analisis ini didukung oleh petikan wawancara berikut ini.

$\mathrm{P}$ : Setelah menggambarkan lingkaran, bagaimana cara Anda menentukan gradien dari garis singgung lingkaran tersebut?

S-29 : Pada gambar terlihat bahwa garis singgung lingkaran tegak lurus dengan garis $P_{1} P_{2}$ maka $m_{1} \times m_{2}=-1$. Untuk menetukan gradien garis yang melalui dua titik yaitu $P_{1}(-2,2)$ dan $P_{2}(10,7)$, saya menggunakan rumus $m=\frac{y_{2}-y_{1}}{x_{1}-x_{2}}$ sehingga diperoleh gradien $m_{2}=\frac{-3}{4}$ dan $m_{1} \times \frac{-3}{4}=-1$ maka $m_{1}=\frac{4}{3}$. Jadi gradien garis singgung lingkaran adalah $\frac{4}{3}$

Hasil analisi yang diperoleh yaitu subjek dapat menghubungkan pengetahuan lama yang telah dipelajari sebelumnya dengan materi baru yang dipelajari yang berkaitan dengan materi persamaan garis lurus dalam menentukan gradien garis yang melalui dua titik dan kedudukan dua garis yang digunakan untuk 
menetukan persamaan garis singgung lingkaran. Dengan demikian, memenuhi syarat kemampuan berpikir reflektif pada indikator ketiga yaitu menghubungkan pengetahuan baru dengan pemahaman terdahulu.

\section{d. Rasionalisasi (Menghubungkan Informasi-Informasi untuk Menyelesaikan Soal yang Diberikan dengan Tepat dan Dapat Menarik Kesimpulan)}

Data ini meninjau kemampuan subjek dalam menghubungkan informasiinfomasi untuk menyelesaikan soal yang diberikan dengan tepat dan dapat menarik kesimpulan (rasionalisasi). Berikut ini hasil pekerjaan subjek S-29.

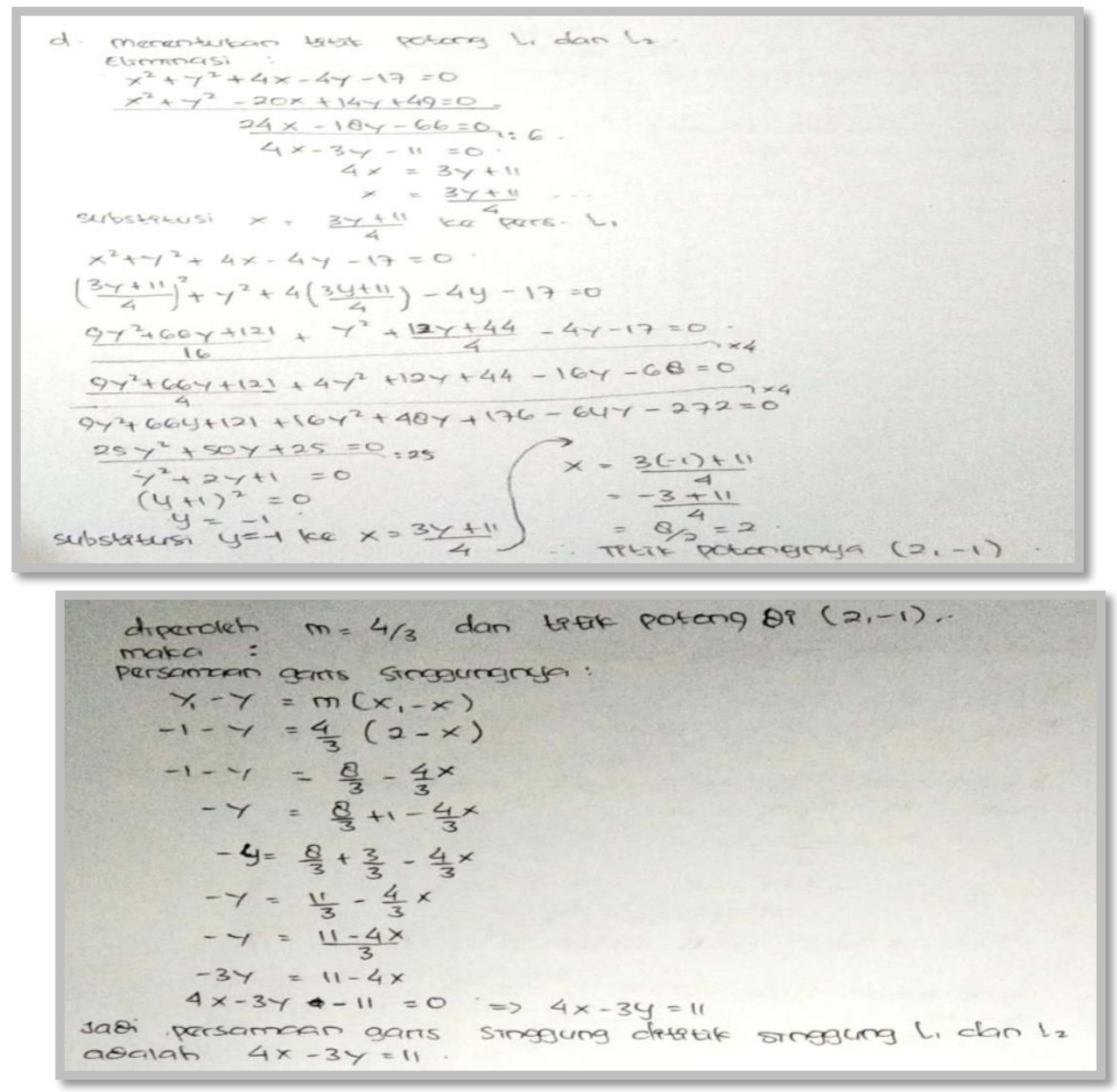

\section{Gambar 6}

Hasil Pekerjaan S-29 
Berdasarkan gambar 6, menunjukan bahwa subjek telah menghubungkan informasi-infomasi untuk menyelesaikan soal yang diberikan dengan tepat dan dapat menarik kesimpulan (rasionalisais). Analisis ini didukung oleh petikan wawancara berikut ini.

$\mathrm{P} \quad$ : Setelah menentukan gradien garis singgungnya, langkah apa selanjutnya yang Kamu ambil untuk menyelesaikan soal tersebut??

S-29 : Karena yang dicari adalah persamaan garis singgung di titik singgung lingkaran $L_{1}$ dan $L_{2}$, maka saya mencari titik singgung/titik potong lingkaran $L_{1}$ dan $L_{2}$

$\mathrm{P} \quad$ : coba Anda jelaskan?

S-29 : untuk mencari titik potong lingkaran tersebut, saya mengeliminasi persamaan lingkaran $L_{1}$ dan $l_{2}$ sehingga diperoleh nilai $x=\frac{3 y+11}{4}$, kemudian mensubstitisikan nilai $x$ tersebut pada persamaan lingkaran $L_{1}$ dan memperoleh nilai $\mathrm{y}=-1$, . setelah itu, nilai $y=-1$, saya substutusikan pada $x=\frac{3 y+11}{4}$ sehingga diperoleh nilai $x=2$. Jadi titik potong kedua lingkaran $L_{1}$ dan $L_{2}$ adalah $(2,-1)$.

$\mathrm{P} \quad$ : Lalu bagaimana dengan persamaan garis singgung di titik singgung lingkaran tersebut?

S-29 : saya menggunakan rumus persamaan garis yang bergradien $\mathrm{m}$ dan melalui titik $\left(x_{1}, y_{1}\right)$ yaitu $y-y_{1}=m\left(x-x_{1}\right)$ dimana $m=$ $\frac{4}{3}$ dan melalui titik $(2,-1)$, kemudian mensubstitusi nilai-nilai tersebut pada rumus sehingga memperoleh persamaan $4 x-$ $3 y=11$. Jadi persamaan garis singgung di titik singgung lingkaran $l_{1}$ dan $l_{2}$ adalah $4 x-3 y=11$

Hasil analisis yang diperoleh yaitu subjek memiliki informasi tentang kedudukan titik terhadap lingkaran, subjek sudah memiliki informasi tentang kedudukan garis terhadap lingkaran, subjek sudah memiliki informasi tentang koordinat titik potong kedua lingkaran, subjek sudah memiliki informasi tentang rumus persamaan garis lurus yang digunakan untuk menentukan garis singgung, subjek menarik kesimpulan dari hasil akhir penyelesaian walaupun pada nomor $2 \mathrm{~b}$ tidak menarik kesimpulan akhir jawaban. Dengan demikian, memenuhi syarat kemampuan berpikir reflektif matematis pada indikator keempat yaitu rasionalisasi. 


\section{e. Menyadari Kesalahan dan Memperbaiki Kesalahan}

Data ini meninjau kemampuan subjek dalam menyadari kesalahan dan memperbaiki kesalahan dalam menyelesaian soal. Berikut ini hasil pekerjaan subjek S-29

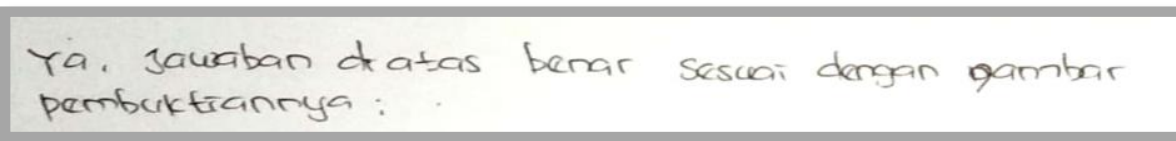

\section{Gambar 7}

\section{Hasil Pekerjaan S-29}

Berdasarkan gambar 7, menunjukan bahwa subjek tmenyadari kesalahan dan memperbaiki kesalahan Analisis ini didukung oleh petikan wawancara berikut ini.

$\mathrm{P} \quad$ : Pada saat menghitung, apakah ada kesalahan yang kamu buat?

S-29 : Iyah, tadi salah tapi sudah saya hapus dan sudah perbaiki.

$\mathrm{P}$ : Pada saat menggambarkan lingkaran dan garis singgungnya, apakah ada kesalahan yang kamu buat?

S-29 : Iyah, awalnya saya menggambar lingkaran salah tapi sudah saya hapus dan perbaikinya.

$\mathrm{P} \quad$ : Setelah menyelesaikan soal tersebut, apakah Kamu yakin dengan Jawaban yang Kamu peroleh?

S-29 : Iyah, saya yakin benar karena sudah mengerjakan secara teliti dan sesuai dengan gambar, jelas bahwa lingkaran $l_{1}$ dan $l_{2}$ bersinggungan luar.

Hasil analisis yang diperoleh yaitu subjek menyadari ada kesalahan pada saat menggunakan keterampilan berhitung dan menggambar dan memperbaikinya, dan Subjek menjelaskan jawaban yang diperoleh benar dan membuktikannya. Dengan demikian, memenuhi syarat kemampuan berpikir reflektif matematis pada indikator kelima yaitu menyadari kesalahan dan memperbaiki kesalahan.

Berdasarkan apa yag telah diuraikan maka kemampuan berpikir reflektif matematis siswa yang berkemampuan matematika tinggi terlihat pada tabel berikut : 


\begin{tabular}{|c|c|}
\hline Indikator KBRM & Hasil Analisis Data \\
\hline Memahami masalah & $\begin{array}{l}\text { Subjek memahami maksud dan tujuan soal } \\
\text { sehingga mampu menuliskan apa yanng diketahui } \\
\text { dan apa yang dianyakan dengan benar }\end{array}$ \\
\hline $\begin{array}{l}\text { Mengkomunikasikan ide } \\
\text { dalam bentuk simbol atau } \\
\text { gambar }\end{array}$ & $\begin{array}{l}\text { 1) subjek mampu menjelaskan bagaimana cara } \\
\text { menggambar lingkaran dengan benar, 2) subjek } \\
\text { menjelaskan cara menggambar grafik persamaan } \\
\text { garis lurus dengan benar, dan 3) subjek bisa } \\
\text { menarik garis lurus yang melalui titk singgung } \\
\text { lingkaran. }\end{array}$ \\
\hline $\begin{array}{l}\text { Menghubungkan } \\
\text { pengetahuan baru dengan } \\
\text { pemahaman terdahulu }\end{array}$ & $\begin{array}{l}\text { Subjek dapat menghubungkan pengetahuan lama } \\
\text { yang telah dipelajari sebelumnya dengan materi } \\
\text { baru yang dipelajari yang berkaitan dengan } \\
\text { materi persamaan garis lurus dalam menentukan } \\
\text { gradien garis dan kedudukan dua garis yang } \\
\text { digunakan dalam menetukan persamaan garis } \\
\text { singgung lingkaran }\end{array}$ \\
\hline $\begin{array}{l}\text { Rasionalisasi } \\
\text { (menghubungkan } \\
\text { informasi-informasi dalam } \\
\text { menyelesaikan soal yag } \\
\text { diberikan dengan tepat dana } \\
\text { dapat menarik kesimpulan) }\end{array}$ & $\begin{array}{l}\text { 1) subjek memiliki informasi tentang kedudukan } \\
\text { titik terhadap lingkaran, 2) Subjek sudah } \\
\text { memiliki informasi tentang kedudukan garis } \\
\text { terhadap lingkaran, 3) Subjek sudah memiliki } \\
\text { informasi tentang koordinat titik potong kedua } \\
\text { lingkaran, 4) subjek sudah memiliki informasi } \\
\text { tentang rumus persamaan garis lurus yang } \\
\text { digunakan untuk menentukan garis singgung, 5) } \\
\text { subjek menarik kesimpulan dari hasil akhir } \\
\text { penyelesaian }\end{array}$ \\
\hline Men & an pada sa \\
\hline
\end{tabular}




\begin{tabular}{|l|l|}
\hline memperbaiki kesalahan & $\begin{array}{l}\text { menggunakan keterampilan berhitung dan } \\
\text { menggambar dan memperbaikinya, dan 2) } \\
\text { Subjek menjelaskan jawaban yang diperoleh } \\
\text { benar dan membuktikannya. }\end{array}$ \\
& \\
\hline
\end{tabular}

\section{KESIMPULAN}

\section{Kemampuan Berpikir Reflektif Matematis Siswa Berkemampuan Tinggi}

Berdasarkan pembahasan hasil penelitian, diperoleh kesimpulan sebagai berikut.

> Memahami masalah yakni ketika subjek mampu memahami maksud dan tujuan soal sehingga mampu menuliskan apa yang diketahui dan apa yang ditanya soal tersebut dengan benar.

> Mengkomunikasikan ide dalam bentuk simbol atau gambar, yakni ketika subjek mampu menentukan unsur-unsur kecukupan dalam menggambar lingkaran dan grafik persamaan garis lurus dengan tepat dan benar.

$>$ Menghubungkan pengetahuan baru dengan pemahaman terdahulu, yakni subjek mampu menghubungkan materi yang baru dipelajari dengan materi yang pernah dipelajari sebelumnya sehingga mampu menyelesaikan soal dengan benar.

> Rasionalisasi, yakni ketika subjek mampu menghubungkan informasi-informasi untuk menyelesaikan soal yang diberikan dengan tepat dan dapa menarik kesimpulan dengan benar.

> Menyadari kesalahan dan memperbaiki kesalahan, yakni ketika subjek menyadari kesalahan dilakukan dalam menyelesaikan soal yang diberikan, kemudian memperbaiki kesalahan tersebut sehingga jawaban yang diperoleh benar dan mampu membuktikan kebenaran jawaban tersebut. 


\section{Kemampuan Berpikir Reflektif Siswa Matematis Berkemampuan Sedang}

$>$ Memahami masalah yakni ketika subjek mampu memahami maksud dan tujuan soal sehingga mampu menuliskan apa yang diketahui dan apa yang ditanya soal tersebut dengan benar.

> Mengkomunikasikan ide dalam bentuk simbol atau gambar, yakni ketika subjek mampu menentukan unsur-unsur kecukupan dalam menggambar lingkaran dan grafik persamaan garis lurus dengan tepat dan benar.

$>$ Menghubungkan pengetahuan baru dengan pemahaman terdahulu, yakni siswa mampu menghubungkan materi yang baru dipelajari dengan materi yang pernah dipelajari sebelumnya sehingga mampu menyelesaikan soal dengan benar.

$>$ Rasionalisasi, yakni subjek mampu menghubungkan informasi untuk menyelesaikan soal pada nomor $2 b$, tetapi mengalami kesulitan dalam menghubungkan informasi-informasi yang ada untuk menyelesaikan soal nomor $3 d$.

Menyadari kesalahan dan memperbaiki kesalahan, yakni subjek menyadari kesalahan pada saat menggunakan keterampilan berhitung kemudian memperbaiki kesalahan dalam menyelesaikan soal nomor 2 dan membuktikan kebenaran jawaban. Sedangkan pada soal nomor 3, subjek menyadari kesalahan pada saat menggunakan keterampilan berhitung tetapi tidak ada jawaban akhir dari penyelesaian soal tersebut.

\section{Kemampuan Berpikir Reflektif Matematis Siswa Berkemampuan Rendah}

> Memahami masalah yakni ketika subjek mampu memahami maksud dan tujuan soal sehingga mampu menuliskan apa yang diketahui dan apa yang ditanya soal tersebut dengan benar.

$>$ Mengkomunikasikan ide dalam bentuk simbol atau gambar, yakni dalam menyelesaikan nomor $1 \mathrm{~b}$ subjek mampu menentukan unsur-unsur kecukupan dalam menggambar lingkaran dan menggambar grafik persamaan garis lurus dengan tepat, tetapi subjek mengalami kesulitan menyelesaikan soal nomor $3 \mathrm{~b}$ dalam menentukan garis singgung di titik singgung lingkaran. 
> Menghubungkan pengetahuan baru dengan pemahaman terdahulu, yakni subjek mampu menghubungkan materi yang baru dipelajari dengan materi yang pernah dipelajari sebelumnya sehingga mampu menyelesaikan soal nomor $1 \mathrm{~b}$ dengan benar, tetapi tidak mampu menyelesaikan soal nomor 3c.

> Rasionalisasi, yakni subjek mampu menghubungkan informasi untuk menyelesaikan soal yang diberikan walaupun jawaban nomor $2 \mathrm{~b}$ belum benar dan subjek mengalami kesulitan dalam menghubungkan informasi yang ada sehingga tidak mampu menyelesaikan soal nomor $3 \mathrm{~d}$.

> Menyadari kesalahan dan memperbaiki kesalahan, subjek menyadari kesalahan pada saat menggunakan keterampilan berhitung kemudian memperbaikinya, tetapi tidak mampu menyelesaikan soal yang diberikan sampai selesai.

\section{DAFTAR PUSTAKA}

Achmad, Munif. 2012. Pengantar ilmu pendidikan. Semarang: UPT UNNES PRESS.

Kusumaningrum, M dan Saefudin, A.A. 2012. "Mengoptimalkan Kemampuan Berpikir Matematika Melalui Pemecahan Masalah Matematika”. Makalah ini disajikan dalam Seminar Nasional Matematika dan Pendidikan Matematika. Yogyakarta: FMIPA UNY.

Mentari, N.,Nindisari, H., dan Pamungkas, A.S. 2018. Analisis Kemampuan Berpikir Reflektif Siswa SMP Berdasarkan Gaya Belajar. Numerical. Jurnal Matematika dan Pendidikan Matematika Vol. 2, No. 1. 69-98. Jakarta: FKIP Universitas Sultan Ageng Tirtayasa.

Mudyaharjo, R. 2010. Filsafat Ilmu Pendidikan. Bandung: PT Remaja Rosda Karya.

Suwardi dan Basrowi. 2008. Memahami Penelitian Kualitatif. Jakarta: Rineka Cipta.

Walgito, B. 2004. Pengantar Psikologi Umum. Yogyakarta: Andi Offset 